\title{
Efficiency Enhancement of Gas Turbine Power Output by Cooling Inlet Air
}

\author{
Ayuba Salihu', Abdul Bariy Akim-Yusuf ${ }^{2}$ \\ ${ }^{1,2}$ Department of Petroleum and Gas Engineering, Faculty of Engineering, Nile University of Nigeria, Abuja, FCT, Nigeria
}

\begin{abstract}
Electrical power generation can be achieved through many means, one of which includes using a gas turbine. Gas turbine performance is highly dependent on ambient temperature; as temperature increases gas turbine power output is lessened. This can be a huge problem in warmer regions like Nigeria. Gas turbines use the surrounding air to generate electricity and this gives rise to a method or curbing the effect of high ambient temperatures. Once the volumetric rate is constant as is the case in a gas turbine system, air density and ambient temperature are inversely proportional; this allows mass flow rate to be inversely proportional to temperature. To fully take advantage of this, there are many methods that can be implemented to achieve this cooling effect. A few of these methods were investigated in this study to determine their strengths and susceptibilities. The performance characteristics were scrutinised for a range of operational values including ambient temperature, humidity and air density. The results showed that air cooling significantly improved the power output of the gas turbine. At standard temperature of $32^{\circ} \mathrm{c}$, the base case was 37.87 MW while evaporative cooler, mechanical and absorption chillers were $37.70 \mathrm{MW}, 40.39 \mathrm{MW}$ and $41.07 \mathrm{MW}$ respectively.
\end{abstract}

KEYWORDS: Air cooling, Ambient temperature, Electricity, Gas turbine, Volumetric rate.

\subsection{INTRODUCTION}

A gas turbine is a combustion engine that can convert natural gas or other liquid fuels to mechanical energy; this energy then drives a generator that produces electrical energy, which is the electrical energy that moves along power lines to homes and businesses (Arabi et al, 2019). To generate electricity, the gas turbine heats a mixture of air and fuel at very high temperatures, causing the turbine blades to spin. The spinning turbine drives a generator that converts the energy into electricity. The gas turbine can be used in combination with a steam turbine (in a combined-cycle power plant) to create power extremely efficiently.

Gas turbines operate in areas of varying climate, usually in rural areas and heavy industrial zones. In order to acclimatize gas turbines to a variety of weather conditions at full capacity, air treatment becomes a necessity. During hot seasons, when atmospheric temperatures are high, there is a great reduction in the output power generated (Kakaras et al., 2006;). Gas turbines are constant volume machines, which means that at a given shaft speed (generator), the same volume of air is moved. Since combustion air is taken from the turbine surroundings, ambient conditions are an important factor in gas turbine operations. As ambient air temperature rises, less air can be compressed by the compressor since it possesses a compressor withdrawing capacity. Similarly, compressor work increases due to limited volume of air available as a factor of ambient temperatures (Xiaojun et al., 2010; Hou et al..2018; Cao, et al., 2017; Carcasci et al., 2017).

Gas turbine performance is highly dependent on the inlet air temperature, whilst its power output depends on its mass flow rate (Popli et al., 2013; Turbine inlet cooling technologies, 2016). This provides the basis for the decline in power output on hot days (low air density). Rising ambient temperatures are inversely proportional to the overall power output (Ejenavi, 2018; Mee, 1999; Kang and Kim, 2018). Many studies have been carried out in an effort to resolve this issue.

Alhazmy and Najjar (2004) carried out a study by employing cooling coil and spray cooling techniques as well as presenting a mathematical framework on which the resulting predictions based and obtained. Analysis shows that the spray cooler reduced the temperature of incoming air by $3-15{ }^{\circ} \mathrm{C}$, enhancing the power by $1-7 \%$ and improving the efficiency by $3 \%$.

Arabi et al (2019) employed the use of off-design analysis in order to navigate this issue on a GE-F5 gas turbine. This was accomplished using MATLAB coding to develop an algorithm capable of predicting performance at off-design conditions. With the aid of the $1 \mathrm{~m} 2$ graph software, equations were derived from the plots of predicted data of various cooling techniques at the same condition. However all the cooling methods employed resulted in a decrease in power generation as compared to the basic cycle. The simulated basic cycle behaved similarly to the actual turbine when operated under the same conditions. 


\section{International Journal of Current Science Research and Review}

ISSN: 2581-8341

Volume 05 Issue 02 February 2022

DOI: 10.47191/ijcsrr/V5-i2-23, Impact Factor: 5.825

Ameri et al (2019) performed tests on the effects of an already installed fog cooling system on the performance of the gas turbine, as well as a technical and economical evaluation on both methods. This resulted in a $13 \%$ increase in power output, outperforming previous expectations of $11 \%$ increase.

Santos and Andrade (2012) simulated a gas turbine environment and employed three cooling methods namely mechanical chilling, evaporative cooling and absorption chilling under predetermined conditions at two sites exhibiting very different humidity, elevation and ambient pressure conditions. It was reported that the absorption cooling method outperformed others under the study conditions. The study concluded that the variation of the ambient air temperature showed that at ISO conditions, an increase of $21{ }^{\circ} \mathrm{C}$ in the intake temperature generates a reduction of $11.46 \%$ in the gas turbine power output and of $7.18 \%$ in the cycle thermal efficiency.

\subsection{MATERIALS AND METHODS}

\subsection{Materials}

In order to carry out this study/evaluation, certain tools and data became a requirement. Some of which were readily available whilst others required assistance to acquire. The required data includes the following:

1. Type and model of gas turbine

2. Flue gas specific heat at constant pressure

3. Fuel Gas Heating value

4. Lower fuel heat value

5. Combustion Temperature (Turbine inlet temperature)

6. Compressor Pressure Ratio

7. Air mass flow rate

8. Compressor isentropic efficiency

9. Combustion efficiency

10. Typical ambient temperature and humidity conditions at the site

11. Amount of power generated

12. Operating Conditions

13. Turbine efficiency

Accompanied by tools such as the Microsoft Excel software as well as the MATLAB software.

\subsection{Methods}

Four cases were simulated in this study namely;

Base case: This is the simulation of the simple gas turbine without cooling. This is the most important simulation of all; there must be a comparison between this case and other scenarios.

Evaporative cooling method: This simulation focused on the first cooling technique, which is highly dependent on inlet air humidity to cool the inlet air. It makes use of both the wet bulb and dry bulb temperatures of the aforementioned air. As there is no actual evaporative cooler, it is possible to assume efficiency values within a reasonable range such as $60 \%$ to $90 \%$ and the temperature range is the same as that for the base case. The simulated was then repeated at $80 \%$ humidity in order to determine whether higher or lower humidity is desired.

Absorption chilling method: Absorption chillers unlike the evaporative coolers; do not depend on ambient temperature or humidity to cool, what matters to them is being able use waste heat to power the mechanism that cools inlet air via heat recovery steam generators (HRSG). The heating source in the generation stage is the HRSG. The absorption chiller makes use of a mixture of two fluids, one acting as a refrigerant (water) and the other as an absorber (Lithium Bromide or ammonia). The water is evaporated from the mixture, condensed then chilled; the chilled water cools the air via a heat exchanger which in turn vaporises the water before it is reabsorbed by Lithium Bromide or ammonia. This cooling method does not draw power from the turbine, making it a good candidate to improve gas turbine output. The ambient temperature of air was varied similarly to the base case.

Mechanical chilling method: Although mechanical chillers are powered by the gas turbine, they are quite similar to absorption chilling, as they are also capable of cooling air regardless of its properties and composition. In fact, their processes are alike, but 


\section{International Journal of Current Science Research and Review}

ISSN: 2581-8341

Volume 05 Issue 02 February 2022

DOI: 10.47191/ijcsrr/V5-i2-23, Impact Factor: 5.825

IJCSRR@ 2022

www.ijcsrr.org

there are also differences. Since the mechanical chiller draws power from the turbine, it is imperative to know how much power it draws from the power generation process. The effect of the coefficient of performance as seen in equation (2.15) on the power requirement was scrutinized, by varying the COP values between 2.0 and 8.0. COP is a ratio of useful heating or cooling provided to work (energy) required. Higher COPs equate to 30 higher efficiency, lower energy (power) consumption and thus lower operating costs. This variation is to analyse which case will be best for the mechanical chiller. The ambient temperature of air was subjected to change within the same range as the base case. Mechanical chillers operate mainly by varying pressure. An expansion valve allows the refrigerant to expand in the evaporator whilst the compressor allows the vaporised refrigerant to cool in the condenser. This is it requires power from the compressor.

\subsection{RESULTS AND DISCUSSION}

\subsection{Base Case simulation results}

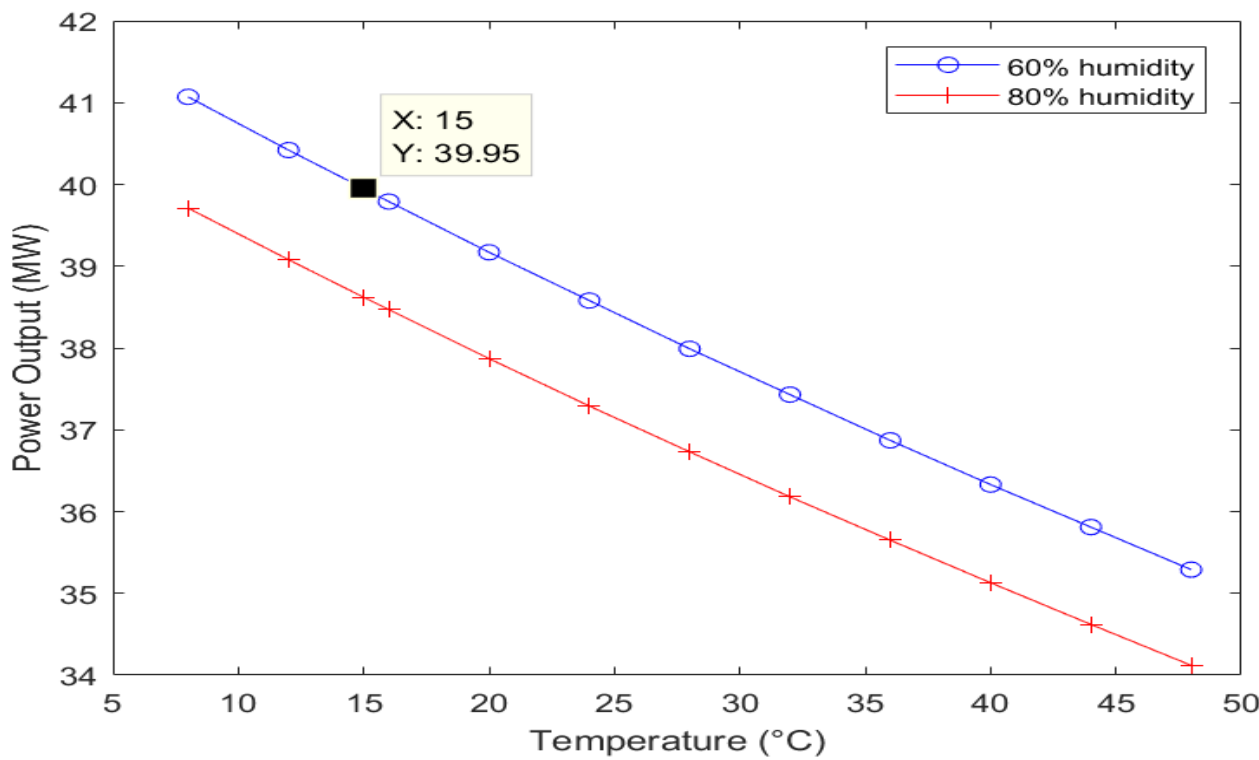

Figure 1: Gas Turbine power output at $60 \%$ and $80 \%$ humidity

This is line with the formula for gas turbine output as seen in the equation below:

$$
\dot{W}_{t}=\dot{m}_{t} \times C_{p \text { avg }}\left(T_{3}-T_{4}\right)
$$

An increase in mass flow rate $\left(\dot{\mathrm{m}}_{t}\right)$ is directly proportional to the turbine output, and mass flow rate is in turn directly proportional to the density of air. Coincidentally, air density reduces with increasing humidity as some of the heavier oxygen and nitrogen gas molecules are replaced with lighter water vapor molecules. Nitrogen and oxygen molecules make up most of the mass of air; thus decreasing the mass per unit volume.

It is quite clear that the less moist air sample (denoted by the blue lines) outperforms the more moist sample. It can also be observed that as temperature increases, the power output reduces, this is due to the fact that gas density and temperature have an inversely proportional relationship according to the real gas law as seen in equation 1.2. This is responsible for the declining the performance of the gas turbine. The ISO condition is marked with the black square $\left(60 \%\right.$ humidity at $\left.15^{\circ} \mathrm{C}\right)$.

Upon close inspection, it can be observed that the performance with respect to temperature is not exactly linear, meaning over an expansive temperature range (albeit unrealistic), the difference in values might not be as pronounced as it is currently. At every temperature conditions, the turbine operating at $60 \%$ humidity outperforms its rival at $80 \%$ humidity by approximately $1 \mathrm{MW}$. The difference is fairly constant over the temperature range with no outlying values. 


\section{International Journal of Current Science Research and Review}

ISSN: 2581-8341

Volume 05 Issue 02 February 2022

DOI: 10.47191/ijesrr/V5-i2-23, Impact Factor: 5.825

IJCSRR@ 2022

\subsection{Evaporative cooling simulation results}

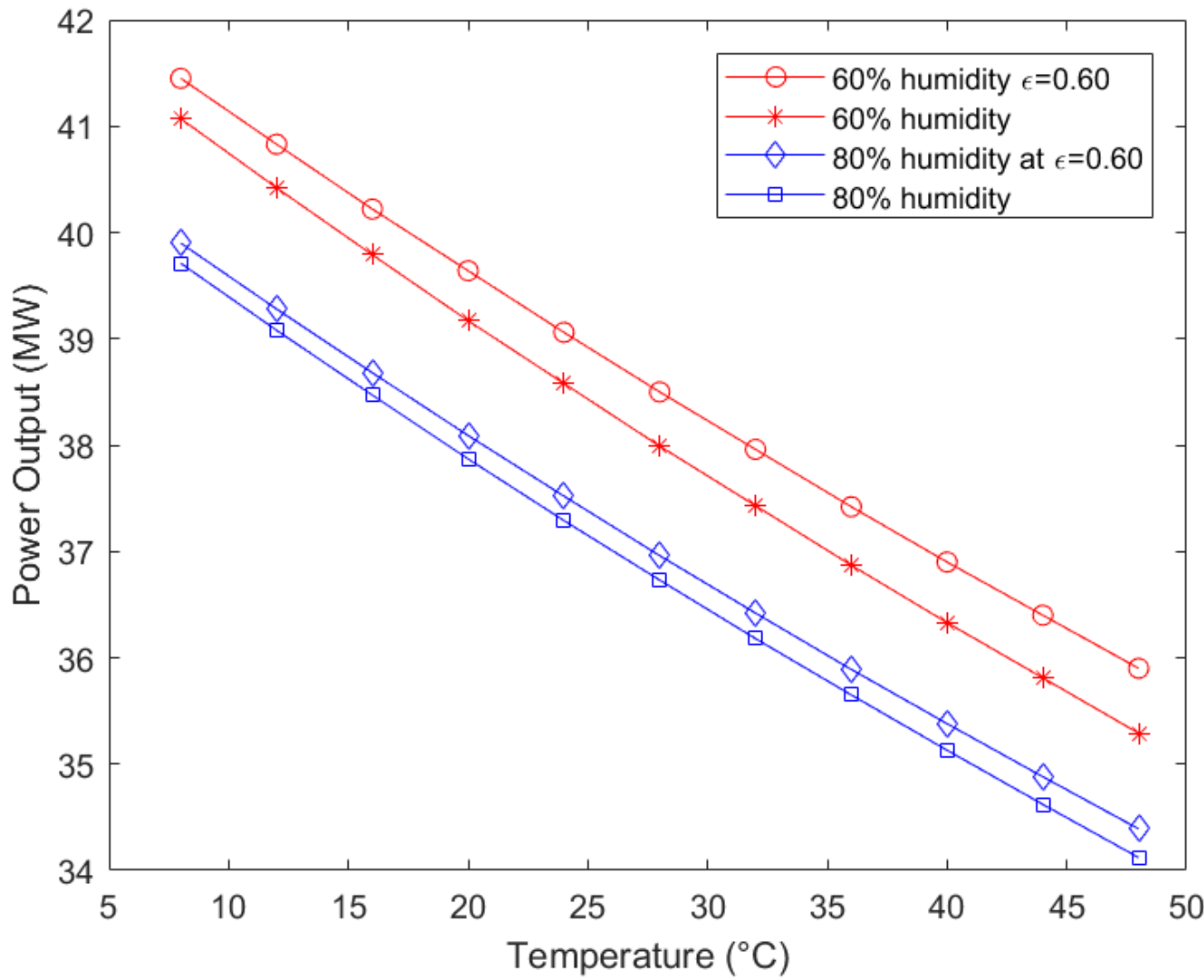

Figure 2: Evaporative Cooling vs no cooling

In the figure above, there is a plot relating gas turbine performance to evaporative cooling at different humidity conditions. In both humidity scenarios, there is a situation where cooling is employed and where it is not.

The effect of humidity is under investigation in this scenario. Evaporative cooling operates by transferring sensible from air to latent heat of vaporisation of water (introduced to the surface of a media). This means the water absorbs heat from the air before being vaporised and carried along with the air stream. For the air to further cool down, the media needs a larger surface (it is corrugated, so it already has a large surface area), or the air must be able to accommodate more water vapour. This is the case here, as air humidity rises; the air is unable to carry more water along, therefore cooling is worse at higher humidity conditions. It has been stated in previous sections of this project, how air temperature affects gas turbine power. Warm or warmer air cannot generate as much power as cool air, these factors serve as the basis for the behaviour of these systems displayed in figure 2 .

It was important to observe the trend in gas turbine performance as a result of evaporative efficiency $(\epsilon)$. It would help ascertain whether a highly efficient evaporative cooler would be needed, as such device would be require more tedious maintenance efforts. Since evaporative coolers use up a lot of water, it is usually employed in areas that have access to large amounts of freshwater as salts can crystallize in the gas turbine system if salt water is used. Evaporative coolers can be relatively inexpensive to install and operate. 


\section{International Journal of Current Science Research and Review}

ISSN: 2581-8341

Volume 05 Issue 02 February 2022

DOI: 10.47191/ijesrr/V5-i2-23, Impact Factor: 5.825

IJCSRR@ 2022

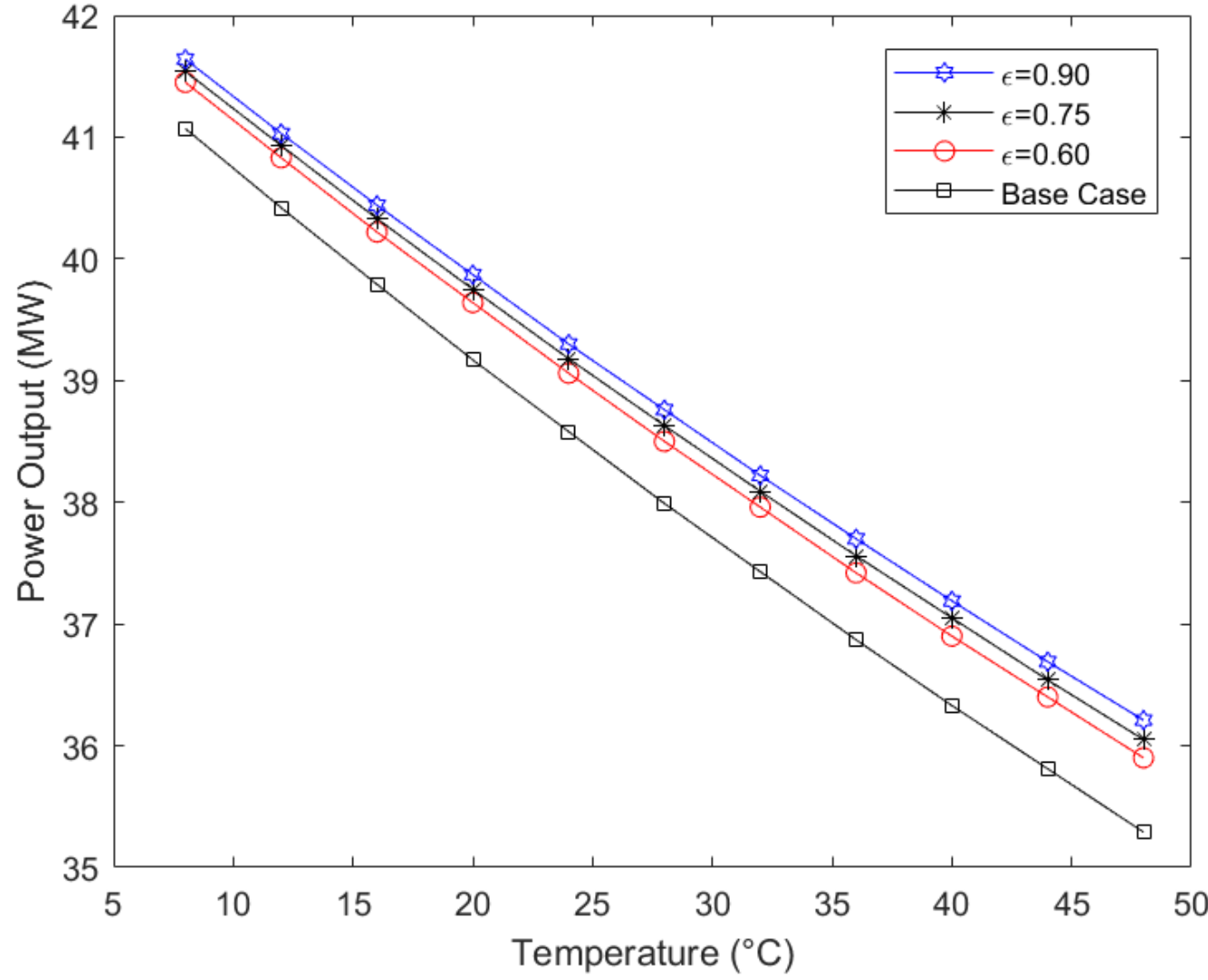

Figure 3: Power Output at varying evaporative effectiveness values

As expected, the most efficient evaporative cooler was more capable of cooling the air eventually producing the most power. The advantage of using a highly efficient evaporative is not so prominent, especially at low temperatures as displayed in the graph; however, its advantage is increasingly noticeable as temperature rises.

In general, all the cooling scenarios that employ evaporative cooling during this investigation perform better than the base case and even more so at higher temperatures.

\subsection{Mechanical chiller simulation results}

Coefficient of performance (COP) is the ratio of refrigeration effect produced by the chiller against the amount of electrical energy required by the cooling machine to generate the cooling effect. It is a measure of efficiency and it is only being considered because the electrical energy required to operate the chiller is from the turbine itself (Kwon et al., 2013).

When the coefficient of performance is higher $(\mathrm{COP}=8)$, it means that it requires less electrical energy from the turbine to cool the air to $8^{\circ} \mathrm{C}$ compared to when $\mathrm{COP}$ is 5 , or 2 accordingly.

All the scenarios recorded the same turbine output power as they were all cooled to the same degree at $60 \%$ humidity. However, due to the operating principle of a mechanical chiller, its source of power is the turbine itself; hence its power requirements must be subtracted from the power generated to give the net power output which was used to develop the plot in figure 4 . 


\section{International Journal of Current Science Research and Review}

ISSN: 2581-8341

Volume 05 Issue 02 February 2022

DOI: 10.47191/ijesrr/V5-i2-23, Impact Factor: 5.825

IJCSRR@ 2022

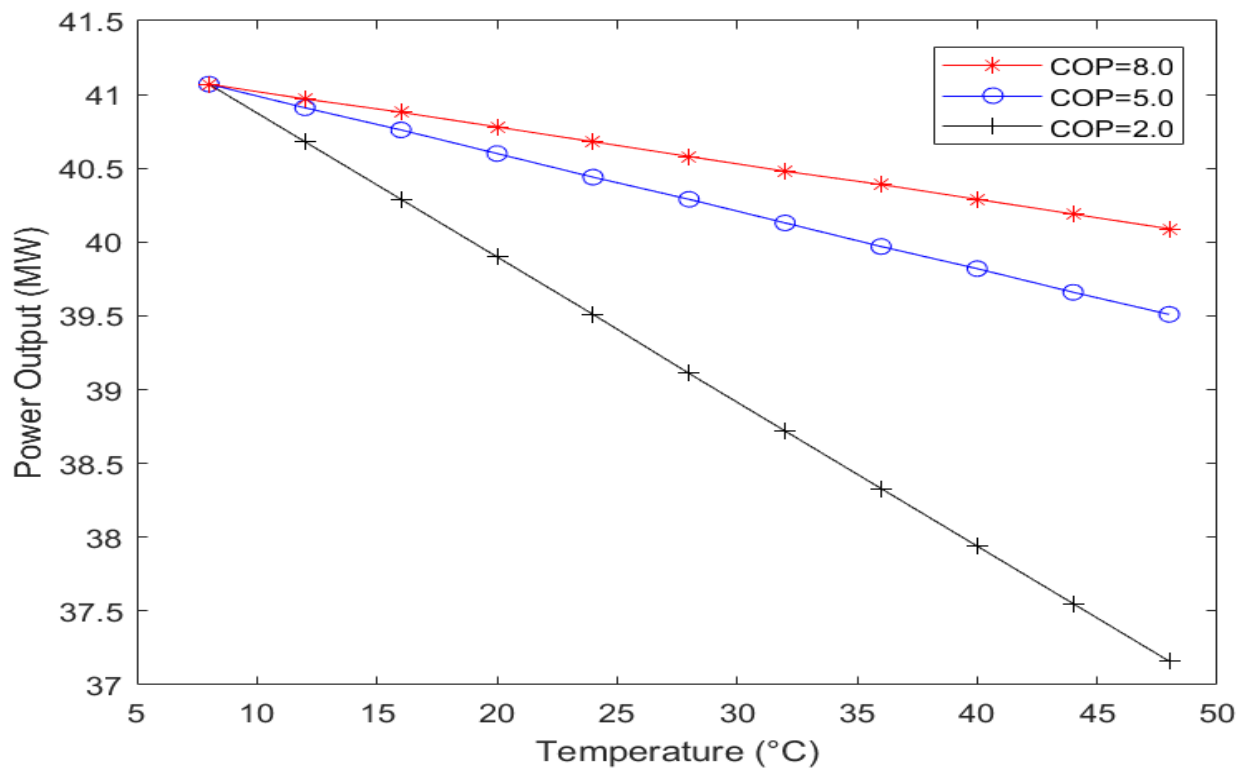

Figure 4: Mechanical chiller with varying COP at $60 \%$ humidity

The mechanical chiller is less effective as the COP reduces. This is because it requires more power to be drawn from the gas turbine system in order to achieve the same degree of cooling. The difference in performance is more prominent as temperature increases and more cooling is required. As the COP increases less power is drawn from the gas turbine to achieve the same cooling effect Unlike evaporative coolers, the efficiency of the cooler or chiller plays a huge role in how much net power the turbine can generate. At the highest temperature, there is almost a difference of $3 \mathrm{MW}$ in the net output of the system compared to the $0.31 \mathrm{MW}$ difference at the highest temperature in evaporative cooler.

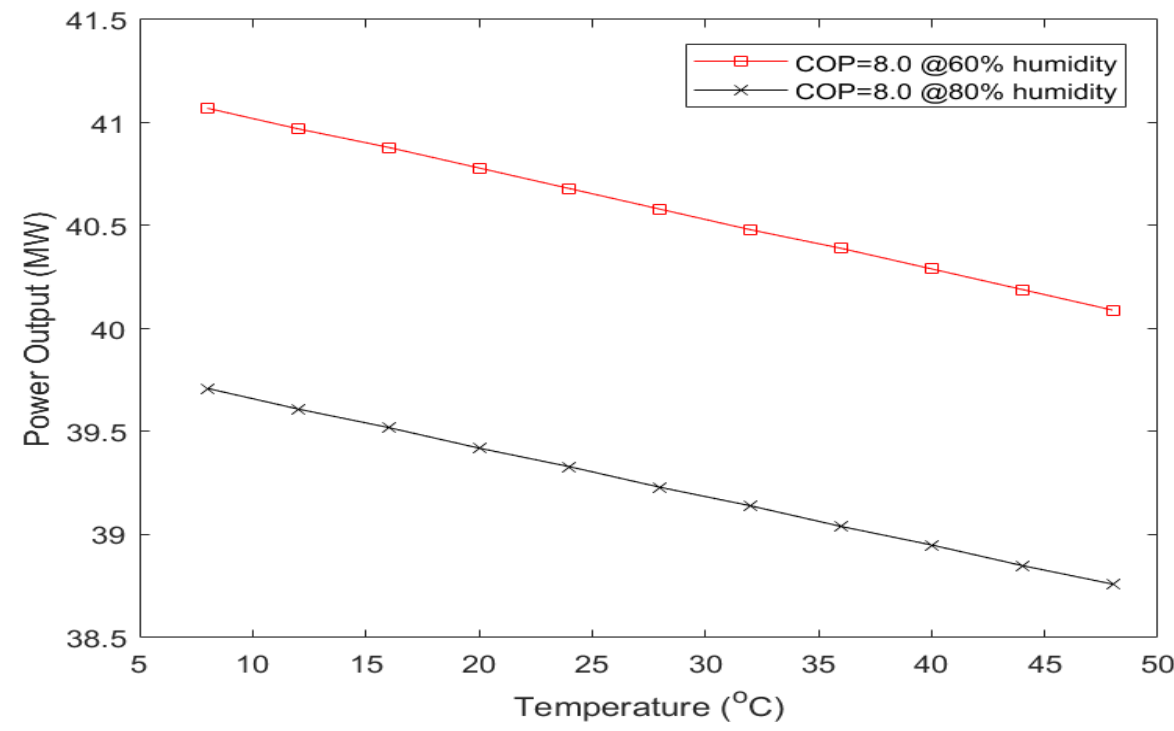

Figure 5: Mechanical chiller performance at different humidity conditions

As humidity increases, it becomes increasingly difficult to improve the gas turbine power output. This is dissimilar to the evaporative cooler where less water can be evaporated into the air stream, instead it occurs due to the fast that moist air is lighter than dry air resulting in a lower mass flow rate of air and subsequently, lower electrical power generated. 


\section{International Journal of Current Science Research and Review}

ISSN: 2581-8341

Volume 05 Issue 02 February 2022

DOI: 10.47191/ijcsrr/V5-i2-23, Impact Factor: 5.825

IJCSRR@ 2022

wWw.ijcsrr.org

\subsection{Absorption chiller simulation results}

Absorption chillers do not draw power from the gas turbine system or depend on the air humidity to achieve cooling. Instead, its power is derived from the exhaust gases from the system using a heat recovery steam generator (Specifications of 7HA.02, 2017; Specifications of mechanical chillers, 2016). There are no parasitic losses; the electricity generated is solely dependent on the degree of cooling desired. Cooling has been set to $8^{\circ} \mathrm{C}$, meaning at simulation condition the air is cooled to that temperature and the power generated occurs as a direct effect of the cooling.

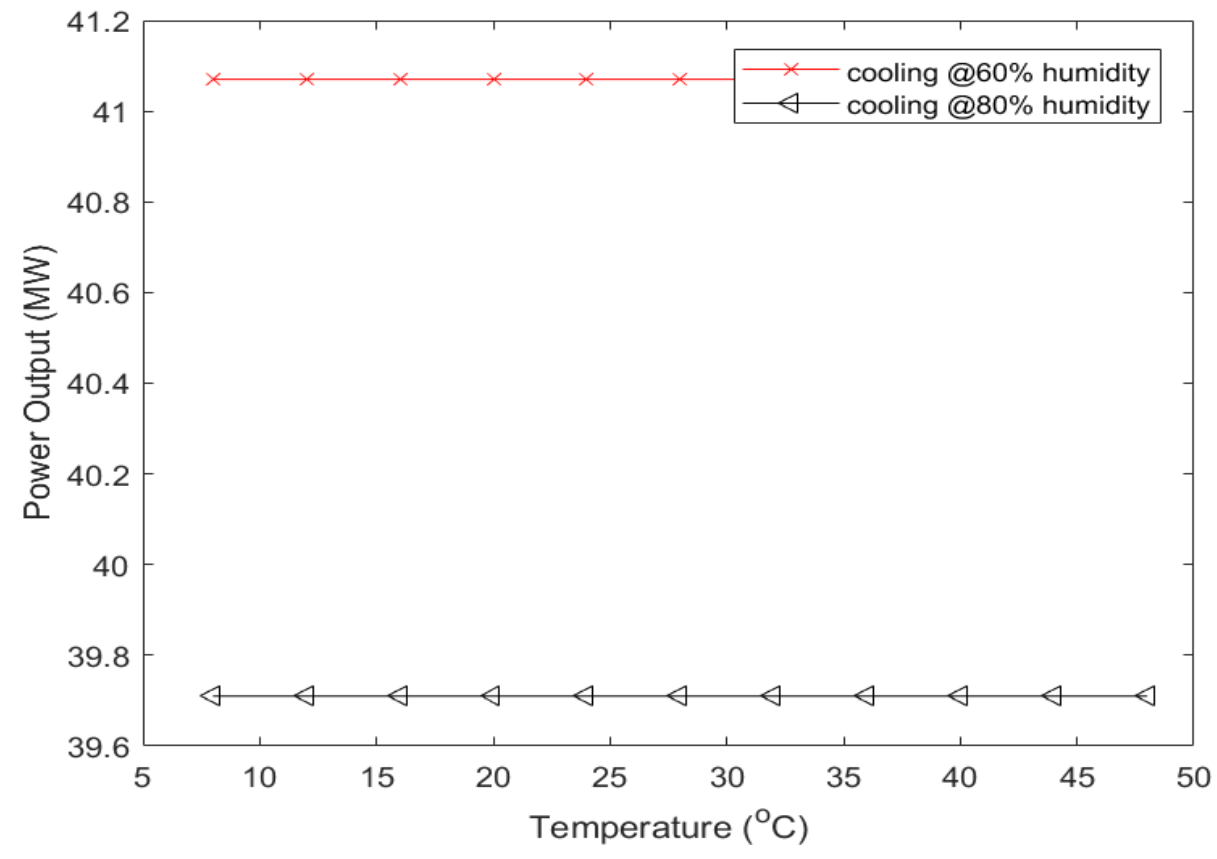

Figure 6: Absorption cooling simulation results

The advantage of using an absorption chiller is that power generated can be considered as approximately constant as other losses are not factored into the simulation.

Humidity also plays a role in the performance of the turbine after cooling in a manner similar to that of mechanical chiller. Moist air is lighter than dry or drier air thereby reducing its mass flowrate and eventually the power that can be generated.

Table 1: Best case scenario under every simulation method

\begin{tabular}{|r|r|r|r|r|}
\hline $\begin{array}{r}\text { Temperature } \\
(\mathrm{C})\end{array}$ & $\begin{array}{c}\text { Base Case Net } \\
\text { Turbine Output at } \\
60 \% \text { humidity } \\
(\mathrm{MW})\end{array}$ & $\begin{array}{c}\text { Evaporative Cooler } \\
\text { Net Turbine Output } \\
\text { at 90\% Efficiency } \\
(\mathrm{MW})\end{array}$ & $\begin{array}{c}\text { Mechanical Chiller } \\
\text { Net Power Output } \\
(\mathrm{MW}) \text { at COP=8 }\end{array}$ & $\begin{array}{c}\text { Absorption Chiller } \\
\text { Net Power Output } \\
(\mathrm{MW}) \text { at 60\% } \\
\text { humidity }\end{array}$ \\
\hline 8 & 41.07 & 41.64 & 41.07 & 41.07 \\
\hline 12 & 40.42 & 41.03 & 40.97 & 41.07 \\
\hline 16 & 39.79 & 40.44 & 40.88 & 41.07 \\
\hline 20 & 39.17 & 39.87 & 40.78 & 41.07 \\
\hline 24 & 38.58 & 39.30 & 40.68 & 41.07 \\
\hline 28 & 37.99 & 38.76 & 40.58 & 41.07 \\
\hline 32 & 37.43 & 38.22 & 40.39 & 41.07 \\
\hline 36 & 36.87 & 37.70 & 40.29 & 41.07 \\
\hline 40 & 36.33 & 37.19 & & 4 \\
\hline
\end{tabular}




\section{International Journal of Current Science Research and Review}

ISSN: 2581-8341

Volume 05 Issue 02 February 2022

DOI: 10.47191/ijesrr/V5-i2-23, Impact Factor: 5.825

IJCSRR@ 2022

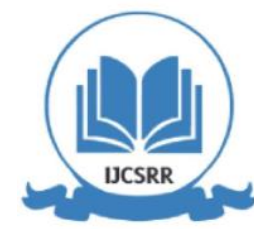

www.ijcsrr.org

All the cooling methods reflected an increase in the power generated, albeit to varying degrees. The objective of cooling was achieved in each case.

\subsection{CONCLUSIONS}

Air cooling has convincingly proven its application in power generation regardless of the method selected from those under investigation. Whilst evaporative coolers have proven to perform best in drier areas with access to water. Absorption chillers offer the best solution; however, they require a high level of modification and piping (HRSG) to facilitate their use. Whereas mechanical chillers offer a similar although at a lesser degree with fewer modifications. Evaporative coolers are highly dependent on properties that cannot be easily manipulated. This study demonstrated that inlet air cooling is capable of generating more power from the gas turbine.

\subsection{ACKNOWLEDGEMENTS}

The authors would like to thank and appreciate the support of Mr. Wale Otun, a representative of the Olorunsogo power plant and the management of Olorunsogo power plant for the data and access to the plant for this study. Our gratitudes also to all the all her colleagues at Nile University of Nigeria, Abuja for their valuable pieces of advice and support.

\section{REFERENCES}

1. Alhazmy, M. M., \& Najjar, Y. S. H. (2004). Augmentation of gas turbine performance using air coolers. Applied Thermal Engineering, 24(2-3), 415-429. https://doi.org/10.1016/j.applthermaleng.2003.09.006.

2. Ameri, M., Nabati, H., \& Keshtgar, A. (2004). Gas turbine power augmentation using fog inlet air-cooling system. Proceedings of the 7th Biennial Conference on Engineering Systems Design and Analysis, 73-78. https://doi.org/10.1115/esda2004- 58101.

3. Arabi, S. M., Ghadamian, H., Aminy, M., Ozgoli, H. A., Ahmadi, B., \& Khodsiani, M. (2019). The energy analysis of GEF5 gas turbines inlet air-cooling systems by the off design method. Measurement and Control (United Kingdom), 52(910), 1489-1498. https://doi.org/10.1177/0020294019877485.

4. Cao Y, Ren J, Sang Y, Dai Y.(2017). Thermodynamic analysis and optimization of a gas turbine and cascade CO 2 combined cycle. Energy Convers Manage, 144: 193-204. https://doi.org/10.1016/j.enconman.2017.04.066.

5. Carcasci, C., Cosi, L., Ferraro, R. and Pacifici, B.(2017). Effect of a real steam turbine on thermoeconomic analysis of combined cycle power plants. Energy, 138:32- 47. https://doi.org/10.1016/j.energy.2017.07.048.

6. Ejenavi, O. W. (2018). Performance Analysıs Of Gas Turbıne Power ( A Case Study Of Delta Iı Gt9 Transcorp Gas Turbine Power Plant, Ughell, Nigeria). July.

7. Hou S, Zhou Y, Yu L, Zhang F, Cao S.(2018). Optimization of the combined supercritical CO2 cycle and organic Rankine cycle using zeotropic mixtures for gas turbine waste heat recovery. Energy Convers Manage 2018;160:313-25. https://doi.org/ 10.1016/j.enconman.2018.01.051.

8. Kakaras, E., Doukelis, A., Prelipceanu, A., Karellas, S. (2006). Inlet air cooling methods for gas turbine based power plants. Trans. ASME., 128: 312-317.

9. Kang, D.W, Kim, T.S. (2018). Model-based performance diagnostics of heavy-duty gas turbine using compressor map adaptation. Applied Energy 212:1345-59. https://doi.org/10.1016/j.apenergy.2017.12.126.

10. Kim, Y.M, Sohn, J.L, Yoon, E.S.(2017). Supercritical CO 2 Rankine cycles for waste heat recovery from gas turbine. Energy 2017;118:893-905. https://doi.org/10.1016/j. energy.2016.10.106.

11. Kwon, I.H, Kang, D.W.\& Kim, T.S.(2013). Using coolant modulation and pre-cooling to avoid turbine blade overheating in a gas turbine combined cycle power plant fired with low calorific value gas. Applied Thermal Engineering;60:285-94. https://doi.org/10.1016/j.applthermaleng.2013.07.008.

12. Mee, T. (1999). "Reduction of Gas Turbine NOX Emissions by Inlet Air Fogging" 18th Annual Power Systems Conference, Iran. Irandanesh

13. Popli S, Rodgers P. \& Eveloy V. (2013) Gas turbine efficiency enhancement using waste heat powered absorption chillers in the oil and gas industry. Applied Thermal Engineering 2013;50: 918-31. 


\section{International Journal of Current Science Research and Review}

ISSN: 2581-8341

Volume 05 Issue 02 February 2022

DOI: 10.47191/ijcsrr/V5-i2-23, Impact Factor: 5.825

IJCSRR@ 2022

https://doi.org/10.1016/j.applthermaleng.2012.06.018.

14. Santos, A. P. \& Andrade, C. R. (2012). Analysis of gas turbine performance with inlet air cooling techniques applied to Brazilian sites. Journal of Aerospace Technology and Management, 4(3), 341-353. https://doi.org/10.5028/jatm.2012.04032012.

15. Specifications of 7HA.02. Products part of Heavy-duty gas turbine of GE; 2017. https://www.gepower.com/gas/gasturbines/7ha.

16. Specifications of mechanical chillers (2016). Products part of EBARA REFRIGERATION EQUIPMENT \& SYSTEMS COMPANY; http://www.ers.ebara.com/en/product/turbo/turbo-rtcsrtcf-series-high-efficiencycentrifugal-chiller-usinglow-pressure-refrigerant.html.

17. Turbine inlet cooling technologies.(2016). Technology Overview of Turbine Inlet Cooling Association. http://www.turbineinletcooling.org/technologies.html.

18. Xiaojun, S., Brian, A., Defu, C. \& Jianmin, G. (2010). Performance enhancement of conventional combined cycle power plant by inlet air cooling, inter-cooling and LNG cold energy utilization. Appl. Ther. Eng., 30: 2003-2010.

19. Yi, J.H, Choi, J.H, Kim, T.S. (2016). Comparative evaluation of variable options for combining a gas turbine and a solid oxide fuel cell for high performance. Applied Thermal Engineering 100:840-8.

Cite this Article: Ayuba Salihu, Abdul Bariy Akim-Yusuf (2022). Efficiency Enhancement of Gas Turbine Power Output by Cooling Inlet Air. International Journal of Current Science Research and Review, 5(2), 505-513 